\title{
Ukrainian Cadastral Exchange File Evolution Path and its Features
}

\author{
Roman Peresoliak, Land Management and Cadastre Department, Uzhhorod National University
}

\begin{abstract}
Ukrainian Land Cadastre has a special place in cadastral ecosystem of the country since Land Cadastre is the primary source of information for other cadastres. Ukrainian Land Cadastre is an implementation of the specific GIS, known as LIS (Land Information Systems). However, such a huge mechanism cannot work without appropriately defined basic components. One of the components is a cadastral exchange file. Thus the definition and quality on the Ukrainian cadastral exchange file becomes very important. This study describes the historical path of the Ukrainian cadastral exchange file, reveals benefits and disadvantages of the cadastral exchange file of the new format based on XML, as well as hidden and unused functionality that potentially could be used in future. To achieve the goal, the following tasks were set: to follow the path of development and formation of the old IN4 format in Ukraine; to define XML functionality; to characterize the cadastral exchange file of a new format based on XML. Given the historical aspects of the development of the Ukrainian cadastral exchange file, the following should be noted: IN4 format is based on INI format; IN4 realizes a simple vector model for describing geometry; a cadastral exchange file should be considered as the file implemented using the cadastral exchange file markup language; the cadastral exchange file implements a topological model; the XML-based cadastral exchange file uses an object-oriented approach to describe complex structured information.
\end{abstract}

Key words: Cadastral exchange file, XML, IN4, GIS

\section{Introduction}

The development of modern land use needs more technological support, and the land register as any large-scale project requires automation of a large part of the manual work. That is a mechanism which will provide the opportunity to view, search, interact with the data in addition to data accumulation. It will have the opportunity to organize network access and control information access policy, the mechanism for generating documentation and much more. The mechanism has been implemented by means of geoinformation systems and technologies (GIS).

An automated system of the state land cadastre of Ukraine could be considered as an analogue of the widely deployed GIS for land management. An important feature of this kind of GIS is the implementation of a large number of automated processes, including registration process of land parcels, their inclusion in the state land cadastre database, the automated formation of paper documents and reports, the generation of cartographic and planned materials, spatial modelling and spatial analysis, the detection of hidden spatial patterns, monitoring of the environment, etc.

Given the specificity of such geographic information systems and their special tools, it is appropriate to classify them as land information systems (LIS). Implementation of the LIS in practice on the territory of Ukraine is functionally expressed in the land cadastre. As it is known, the land cadastre among other cadastres has a special and fundamental place because land cadastre is the primary source and the source of basic information for other cadastres. In particular, the land cadastre is the basis for [23]:
- cadastre of water resources;

- cadastre of natural plant resources;

- cadastre of resources of the animal world;

- cadastre of natural therapeutic resources;

- cadastre of mineral resources, minerals, manifestations, and minerals of man-made deposits;

- cadastre of forest resources [14];

- cadastre of natural areas of the resorts [20];

- cadastre of territories and objects of the natural reserve fund [21];

- municipal cadastre [22];

- cadastre of the anthropogenic emissions and removals of greenhouse gases [24].

However, land cadastre, LIS and GIS, in general, use only the platform for implementation of a variety of tools for solving land management issues. By itself, the tool is not able to solve all diversity of functions assigned to it without the existence and functioning of an ecosystem of technological, normative and methodological levels. In particular, one of such levels can be considered to be the basis of electronic document flow of land cadastre, i.e., cadastral exchange file.

As the cadastral exchange file is important in the cadastral system of Ukraine, consideration of its features and the process of its formation is of crucial importance. This study describes the historical path of the Ukrainian cadastral exchange file and points at benefits and disadvantages of the cadastral exchange file of the new format based on XML, reveals hidden and unused functionality that potentially could be used in future. To achieve the goal, the following tasks were set: to follow the path of development and 
formation of the old IN4 format in Ukraine; to define XML functionality; to characterize a cadastral exchange file of new format based on XML.

\section{Methodology of research and materials IN4 cadastral exchange file format}

According to [25], the exchange file is a unified structure of the land cadastre data containing the results of the performed land management activities in electronic form intended to unify the land cadastral data on the land plot or their collection in electronic form and contains: metric, semantic and service information. An important feature of the IN4 format is that it is presented as a text file in ASCII codes using code table 1251 (Code 1251). It is not allowed to use other code pages to create an exchange file.

The use of this code table, also known as Windows-1251 [4], is inherent for Windows family operating systems and can represent encoded characters for Ukrainian, Belarusian, Serbian, Bulgarian and Russian [30]. This feature significantly limits the amount of information entered, as it is possible to insert characters only of the above mentioned languages and Latin characters; all others will be considered incorrect.

The IN4 exchange file consists of structural blocks of land cadastral data [25]:

- cadastral quarter;

- parcel;

- land type;

- cadastral zone;

- cadastral unit substitute.

Structural blocks are clearly associated with spatial layers that environment can generate.

Each structural block of the land cadastre data contains lines with a fixed number of structural fields of metric information (rectangular coordinates in the Gauss-Kruger projection) and semantic (attributive) information of the cadastral unit. Each line (tag) begins with the keyword (descriptor) connected by the symbol "=" (equality sign) with the string containing the fields of land cadastral data. As a delimiter of the line fields and the end of the line, the character "," (comma) is used. The absence of the "," (comma) symbol at the end of the line indicates the completion of the land-cadastral data transfer to the block [25].

The data of the strings of semantic information is limited to the character "'"'(the quotes are the ASCII character code 034). The data of the lines of metric information are not limited by the "'" character (quotes). When the metric information is taken as a delimiter of the whole and fractional part of the number, the symbol "." is used (point). If the semantic information contains a character "'",'(quotes), for example, in the proper name of the subject of the land relations, then the "l" (slash) is inserted before the quotes. The "\#" (hash) symbol at the beginning of the line converts the string to comment [25] This approach allows to save a set of characters that better describe the data in the file and are ignored by the program that processes the file.

\section{XML basics}

XML (Extensible Markup Language) describes a class of data objects called documents, and briefly describes the mechanization of document processing using computer programs. An XML document consists of container elements that are called entities. The markup in the document serves as a description of the document itself and the logical structure. Also, XML provides a mechanism for imposing restrictions on the storage scheme and the logical structure. XML also includes a program module called the XML processor used to read documents, search data, access the structure [2, p. 1].

In general, an XML document contains one or more elements, each of which is marked with an initial and a final tag, or in the case of a blank element, an empty tag. Each element has a type defined by its name, called the "base identifier," and may contain a set of non-mandatory attributes [2, p. 14].

Often it is possible to find the "XML document", "XML technology", "XML document". However, what is actually XML is? At the first level, XML is a protocol for storing and managing information. At the next level, this is a family of technologies that can help to do everything from document execution to data filtering. At the highest level this is the philosophy of information processing, the purpose of which is to ensure the maximum benefit and flexibility of the data by providing them with the purest and structured form [6, p. 13].

It would be nice to remember that single name (XML) contains simultaneously many related values, which often leads to confusion. Regardless the name itself, XML is not a markup language: it is a set of rules for creating a markup languages [6, p. 13].

As mentioned above, XML represents a whole set of technologies that work closely with each other. In the author's opinion, it is the excellent workflow and the number of these technologies that allows you to store XML in the first positions, since it is not the only representative of the markup languages, which can be attributed to JSON Schema [13]. Checking and generating new, simpler documents such as JSON or YAML, is gaining popularity [28], but the most advanced set of technologies in XML tools leaves it at the forefront. According to [31], the tools contained in XML are shown in the Figure 1.

When storing a large amount of data using XML, it is important to pay attention to the exact place that holds among the data models. This question becomes extremely important if we consider XML not as a 
mechanism for describing data but as a means of preserving it. This is confirmed by a number of sources $[16,1,32]$. In the author's opinion, the consideration of XML really becomes a data storage system, since this interpretation is due to the developed set of technologies that offers XML [1].

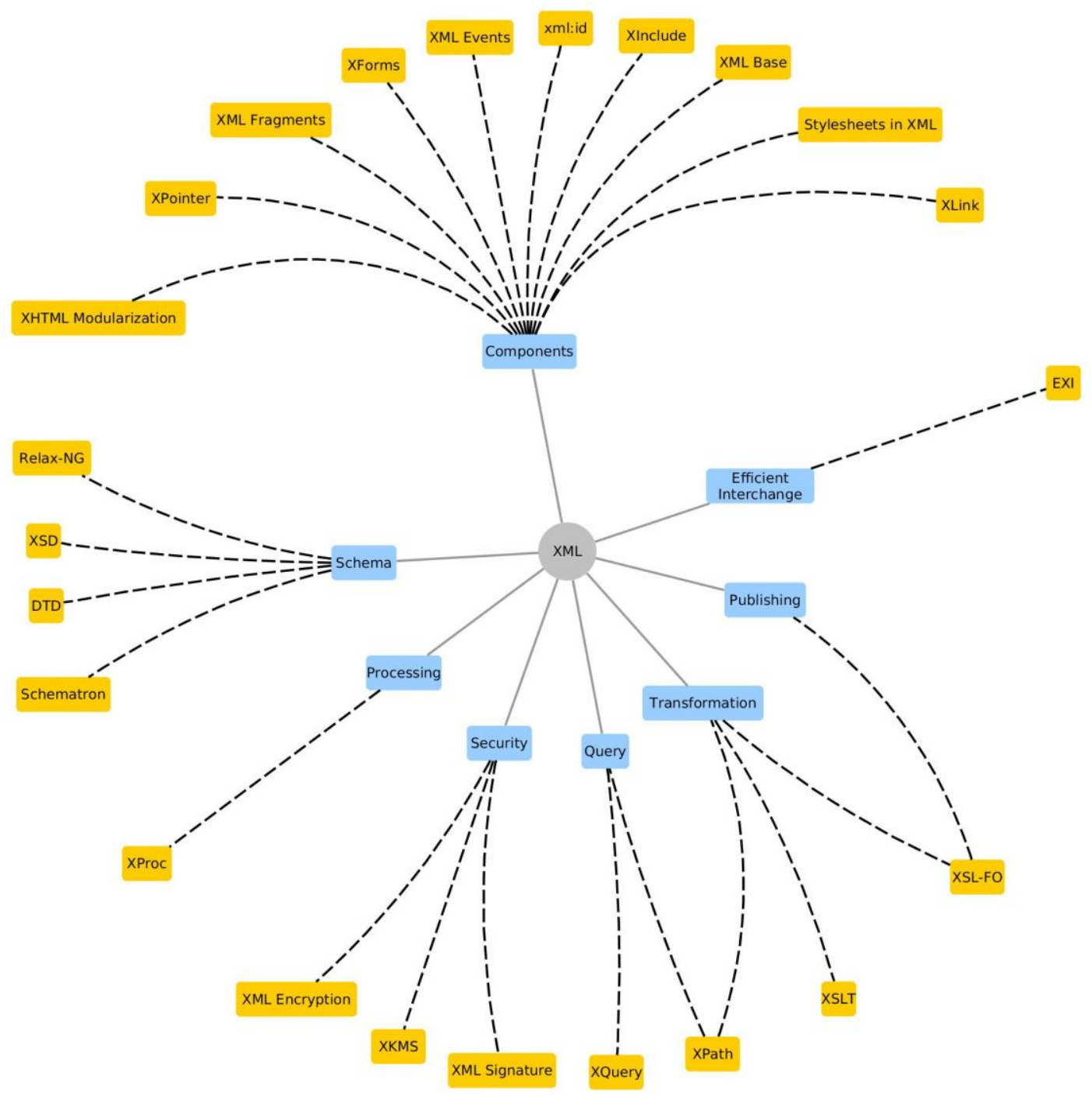

Fig. 1. XML components

Given the use of XML on the territory of Ukraine in the field of cadastre, it, first of all, should be considered as a means of describing the complex structured information, and only then as mechanics of its preservation. In the author's opinion, this approach justifies the use of just XML, but not other similar technologies.

\section{Discussions and results}

IN4 structure features

Given the types of attribute information that can be used to implement this data format, it is worthwhile to elaborate on how data types display end attributes, that is, the preservation of certain specific information.

IN4 offers the following implementation of attribute data on the basis of numeric and string types:

- numeric

- simple

- string

- simple

- denormalized

- consistent

- variational

- composite

Simple numeric and simple string attributes are the simplest form of data storage: 
\# Area unit

$\mathrm{SZ}=" \Gamma \mathrm{a}$. . ,

\# Parcel area value

$\mathrm{AS}=0.2481$

Fig. 2. Simple numeric and simple string attributes

The large amount of data stored in IN4 by its very nature is not atomic data, but they are a collection of data. It is this type of string attributes can be classified as denormalized.

\# chairman of executive body

$\mathrm{GL}="$ Петренко Іван Васильович"

Fig. 3. Denormalized string attribute

Figure 3 demonstrates how a group of data that can represent several independent attributes are combined into one. This approach eliminates the flexibility of access to information, and makes a detailed search complicated. Also, some of the attributes partly adhere to the atomicity of the data but retain them in a clearly defined sequence:

\# Address structure

AU $=$ "<country code >, <index >, <district>, <region>, <settlement with type >, <street with type >, <building >,

$<$ department $>,<$ flat $>"$

\# Address example

$\mathrm{AU}=" 804,07416$, Київська , Броварський , с . Погреби , вул . Лугова , 12 , - ,1"

Fig. 4. Consistent string attributes

The disadvantage of the approach in Figure 4 is the positionality of parts of the attribute field, which makes filling and the presence of a special notation to fill in empty fields ("'"”) complicated. Also, it should be noted that not all parts of the attribute field observe atomicity. So, for example, a town and a street also contain information about the type of settlement and type of street.

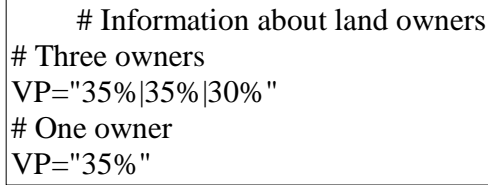

Fig. 5. Variational string attributes

The types of attribute string fields that may contain multiple attributes in a row can be attributed to the variational attributes. The feature of this kind of attributes is that they can contain one mentioning of attribute values or several. Compositional attribute fields can be attributed to the last type of attributes.

\# Metric information (one point example) )

$\mathrm{N}=1, \mathrm{NP}=" 172$, $\mathrm{X}=55398$ 80. $30, \mathrm{Y}=4254468.52, \mathrm{H}=125.03, \mathrm{MX}=0.02, \mathrm{MY}=0.02, \mathrm{MH}=0.05$

Fig. 6. Composite string attributes

That is, the line of metric information is responsible for preserving the spatial description of the object. In spite of the fact that there are several keys at the same time, this record representing the same line in the file is one and indivisible attribute.
Another feature of representing spatial information by IN4 locks is the use of a spaghetti model. This can clearly be metric information of the exchange file:

$\mathrm{N}=1, \mathrm{NP}=" 172 ", \mathrm{X}=55398$ 80. $30, \mathrm{Y}=4254468.52, \mathrm{H}=125.03, \mathrm{MX}=0.02, \mathrm{MY}=0.02, \mathrm{MH}=0.05$ $\mathrm{N}=2, \mathrm{NP}=" 172 ", \mathrm{X}=55398$ 80. $30, \mathrm{Y}=42544$ 68. $52, \mathrm{H}=125.03, \mathrm{MX}=0.02, \mathrm{MY}=0.02, \mathrm{MH}=0.05$

Fig. 7. IN4 spaghetti vector model

Historical prerequisites for the formation of IN4
Despite rather narrow specialization of this format and the limited scope of application, which can be attributed to the territory of Ukraine, when applying 
exclusively in the field of land cadastre, the format can follow a fairly clear path of development. As it is known [5, p. 272], this format has grown from the most popular Invent Grad system; later it was duly amended and approved for the use of land resources. The format has a simple syntax. With some skills, you can easily create and edit it using simple tools such as Notepad. Today, IN4 was officially abolished on the territory of Ukraine and replaced by the XML format. Nevertheless, the files of this format are found quite often, given the large number of previous activities. IN4 on the territory of Ukraine has operated since May 23, 2003 [25].

It should be noted that up to $[27$, p. 3,26, p. 7,10 , p. 88,12, p. 14] it becomes apparent that IN4 is to some extent based on the GBD format and is sometimes considered as one and with the format [26, p. 7]. The mentioned format contains information about the coordinates of the land and internal economic system. GBD data represent a set of point objects from the [18, p. 175] typed attribute attributes for them. According to [27, c. 20], the GBD file is a character and is created in the form of delimited keywords, where the character "\#" converts the file's record into a comment.

Indeed, the similarity of the formats IN4 and GBD, in terms of preserving geometry, is unprincipled. For the format, for example, the continuation of the spatial information [12, p. 268] completely corresponds to the format adapted for the territory of Ukraine:

As you can see in Figure 8, the field of information about the GBD format almost completely repeats the form of recording metric information of the IN4 cadastral file. That is, it is possible to clearly state the origins of the IN4 format from the InventGrad system and origins of the adapted IN4 format for the land cadastre of Ukraine from GBD format. However, from the mentioned above and considering the name of the IN4 format, it is possible to try to make a deeper analogy of this family of formats (GBD and IN4) with previously existing data formats, namely, the format of the configuration files - INI. The sources of GBD and IN4 formats in the INI format indicate a number of links, namely:

- $\quad$ string is an attribute;

- the attribute is described by the key-value type token, where the separator is the "=" sign;

- attributes can be numeric and string (data limited by pins “"'”);

- character "," as a delimiter of several values;

- the possibility of using independent data blocks;

- character as a comment;

- non-fixed formats;

- file encoding;

- other.

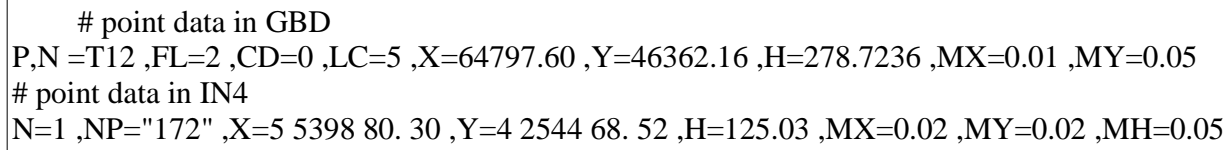

Obviously, due to the lack of clarity of the INI format and the lack of its specification, [8] variations in its implementations may be somewhat different. This applies to which character will be used as a comment, or if one wants to use the characters "'" as a metric for string attributes, but overall, the syntax remains the same. For the best analogy between INI and IN4 (GDB), it necessary give an example [7]:

[ SNAServerAutoTPs ]

BounceTP=bnceprms

TestTP=testprms

[bnceprms]

PathName $=c$ : Isnalwbounce.exe

LocalLU=Eric

Fig. 9. INI file example

As it can be seen in Figure 9, the configuration file contains logical blocks (elements in square brackets), similarly as in the IN4 representing the layers. This assumption is supported by the popularity of parser programs that can read the INI syntax for many programming languages. A part of the test file IN4 when reading a parser is shown in Fig 10. 
BL,

$\mathrm{DS}=" 1210100000 "$,

$\mathrm{SZ}=$ "г а . " ,

$\mathrm{SR}$,

$\mathrm{SC}=" 0200021 "$,

$\mathrm{AD}=$ "м . Дніпро , просп . Кірова , $93,-"$,

$\mathrm{N}=1, \mathrm{NP}=" 104 ", \mathrm{X}=5574440.92, \mathrm{Y}=3372897.52$,MX=0,MY=0,

Fig. 10. IN4 sample

An error was received because the blocks, which in this case are presented as BL and SR, are not properly formatted, but the file is presented as a file. We receive a complete IN4 file that is designed in accordance with the requirements of INI. However, due to the compositional nature of the metric attributes, it is worth noting that they can be flashed as an INI file, since at the base level it returns all values as the single string attribute. In view of this, in the author's opinion, it is possible to speak about the presence of the INI format in IN4 format. The developed technology is shown in Figure 12. It is also worth adding that the name of the format may lead to misunderstanding due to the lack of detailed information. In particular, there is the so-called IN5 $[18, p .172]$ format, which is called the new format of an XML-based cadastral file.

Therefore, in the author's opinion, it is important to note how exactly consider the file extension IN4. Due to the expansion of .info [9, 11] and .inf [17], however, with the need to keep a file association as informational, an unofficial approach was used to replace associative words with numbers. Therefore, IN4 should be pronounced as IN(in)4(four) or info.

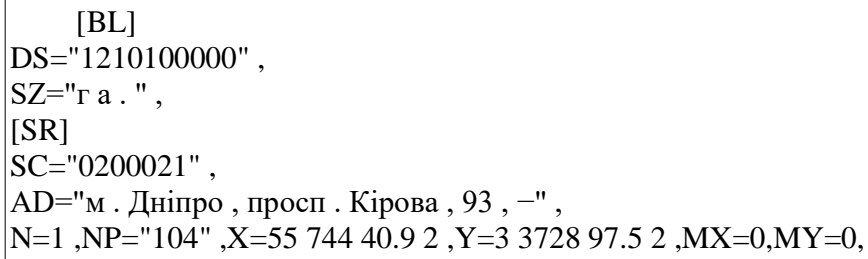

Fig. 11. Updated IN4 sample

It can also be assumed that the digit at the end of the extension indicates a generation or version of the format, where "IN" indicates the use of the INI format as the base one, and "4" indicates versatility. However, even in this case, the IN4 has not undergone any changes and improvements to the release of the fifth generation since it was replaced by a new implementation that uses XML technology as a base.

However, due to the lack of IN1, IN2, and IN3, the version approach mentioned above seems to be ineffective. Therefore, in the author's opinion, IN4 should be considered as a file containing information or as info(IN4).

\section{Features of the XML-based cadastral exchange file structure}

With the introduction of a new cadastral exchange file, based on XML, document filling and the approach to document creation, significant changes have taken place.

By analogy with IN4, here, in addition to preserving the information itself, the logical sections of the information appear and join them into groups. However, it should be noted that the formats are strikingly different in nature, and making any direct analogies, in the author's opinion, are inappropriate.
However, comparing the form of preservation of information made for mechanism format deserves attention. Since, in the author's opinion, the very complex nature of cadastral information has led to a change in technology.

An important feature of the new cadastral exchange file is that it is the same as other XMLbased formats, of which you can often refer to the most commonly used ones:

- SVG (Scalable Vector Graphics) [29, c. 2]

- GML (Geography Markup Language) [19, c. 6]

- KML (Keyhole Markup Language) [3, c. 26]

- SLD (Styled Layer Descriptor) [15, c. 6]

It is not just the format of the document but the entire markup language. So by means of analogy one can clearly state that the cadastral file is the result of the generated document executed using the cadastral exchange file markup language.

Since any language that uses XML must have a file schema, that is, a set of rules, then the cadastral exchange file markup language should have it. Consequently, the Digitals software contains a schema file called "IN4XMLSchema.xsd". This file can be considered as a file description of the rules for cadastral exchange file markup language.

As it was described before, XML is a relevant mechanism for describing complex structured 
information and for reproducing the object nature of data. Despite the fact that interrelations between data in XML are formed by inserting one node in another, one can assume that in this case the data has a treelike structure, however, the elements of the tree that are repeated or can be repeated in a constant form, in fact, also transform a set of node trees into objects, because it is necessary to perform a formal description by modulating the document, which will answer the question correctly whether it is executed or not.

It is obvious that describing the entire document by a scheme without its logical division into a subset is not convenient and generally leads to the complexity of supporting such schemes. Therefore, in the author's opinion, it is necessary to allocate components of the scheme which should be considered as objects. Objects in the author's interpretation are XML Schema components that can be represented using the XML Schema terminology exclusively by the end-node XML document (xsd: element), which can consist of both simple (xsd: simpleType) and complex (xsd: complexType) types for describing nested nodes, their attributes, and interrelationships between them. An object is a container for storage of structured information.

This approach, in the author's opinion, is suitable to work better with documents executed using XML and cadastral files, in particular. This method allows us to assess the level of implementation of the technological potential of the XML object mapping in the cadastral exchange file markup language. However, it should be noted that this approach is implemented in the language of markup cadastral files of the first generation exchange only partially.

Consequently, the problem of structured information cadastral exchange files that are implemented using XML technology is solved by presenting this information in the form of objects.

So, for example, a block of information about the address is implemented as a structure and has the form:

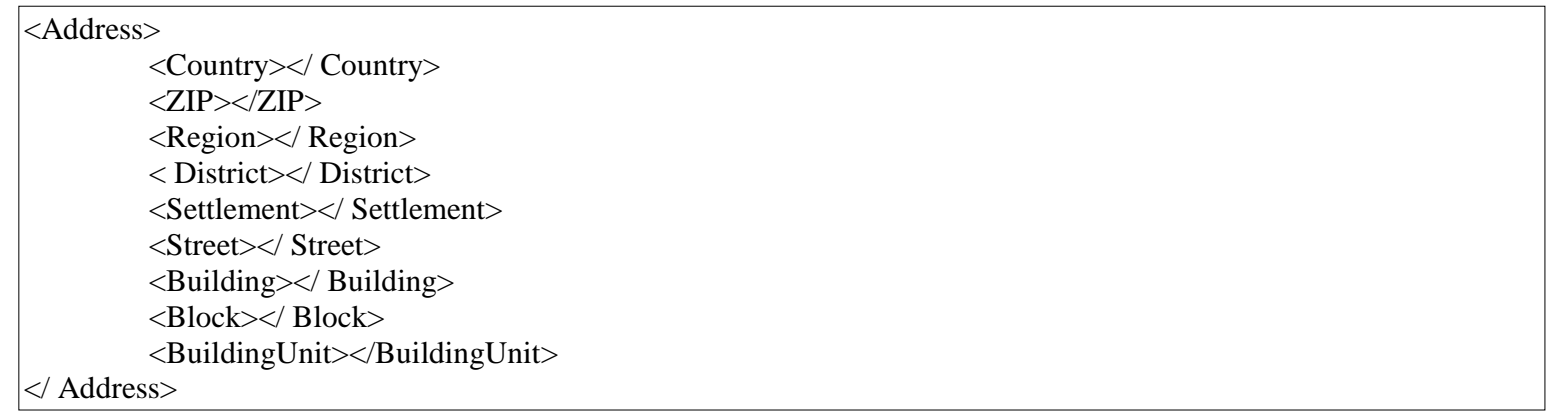

Fig. 12. The address presentation of the first generation cadastral exchange file markup language

It is also worth noting that the usual division of information into groups using layers that can be found when generating cadastral exchange file using Digitals software is absent in the structure of the cadastral file executed using XML. In contrast, IN4 stores data belonging to the layer consistently. It should be noted that the vivid example of this is the mechanism of spatial information preservation, since it is a component that more closely distinguishes the process of storing XML data from the approach of storing IN4 data. 


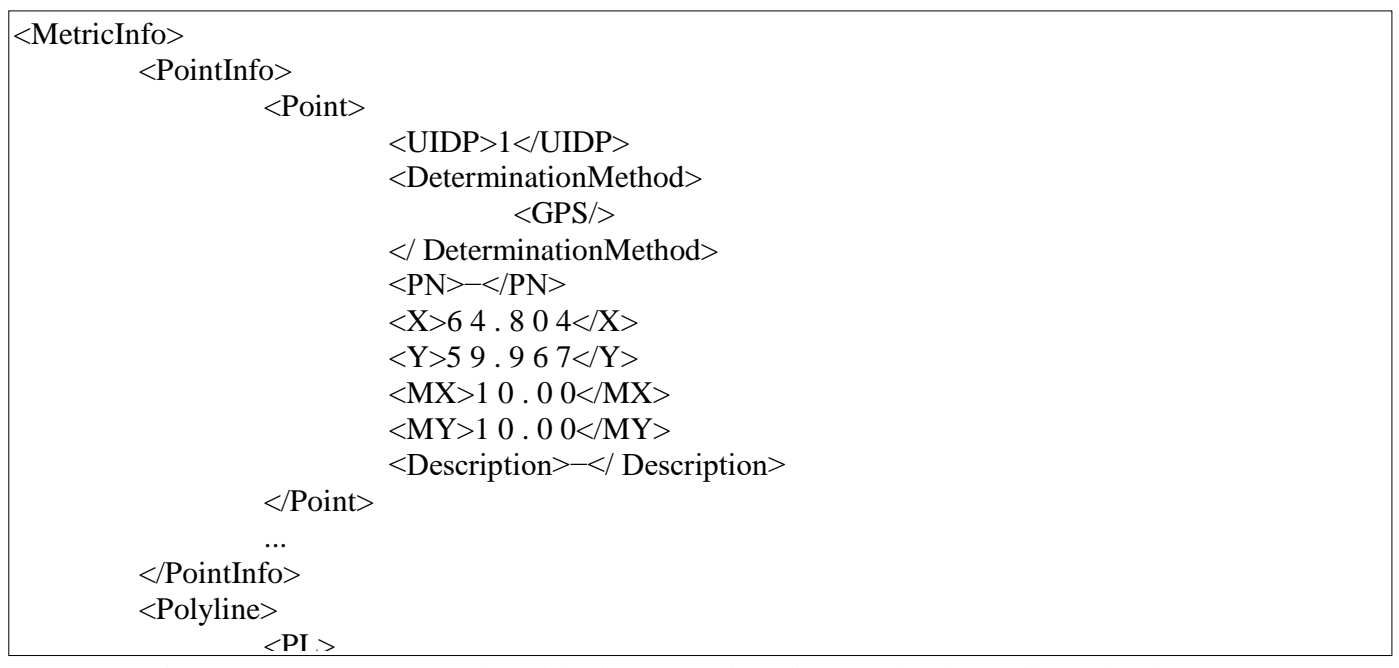

Fig. 13. Geometry representation of the first generation of cadastral exchange file markup language

As can be seen from the representation of a simple vector model, the deductions in XML are presented. In contrast to the spaghetti model, the topological model is taken. It is important to note that the analogue of the linear-node topology is used here.
The POLYVRT model is based on the fact that "PL" is an analogue of the chain and may contain several points, which in particular is confirmed by the data schema "IN4XMLSchema.xsd":

<xsd:element name="P" type=" xsd:int " minOccurs=" 2 " maxOccurs=" unbounded " default=" 0 ">

Fig. 14. Point links of the first generation of cadastral exchange file markup language

The number of elements "P" can vary from a range of 2 to infinity. However, an axial element is only half way to determine the ultimate geometry of the object, since there is no data which particular polyline belong to the object. The above data is included without restriction in the data group of a particular object, and has the form. The Figure 16 displays the assignment of the previously defined polylines of the object. It is worth noting that this is a realization of the polygonallinear topology.

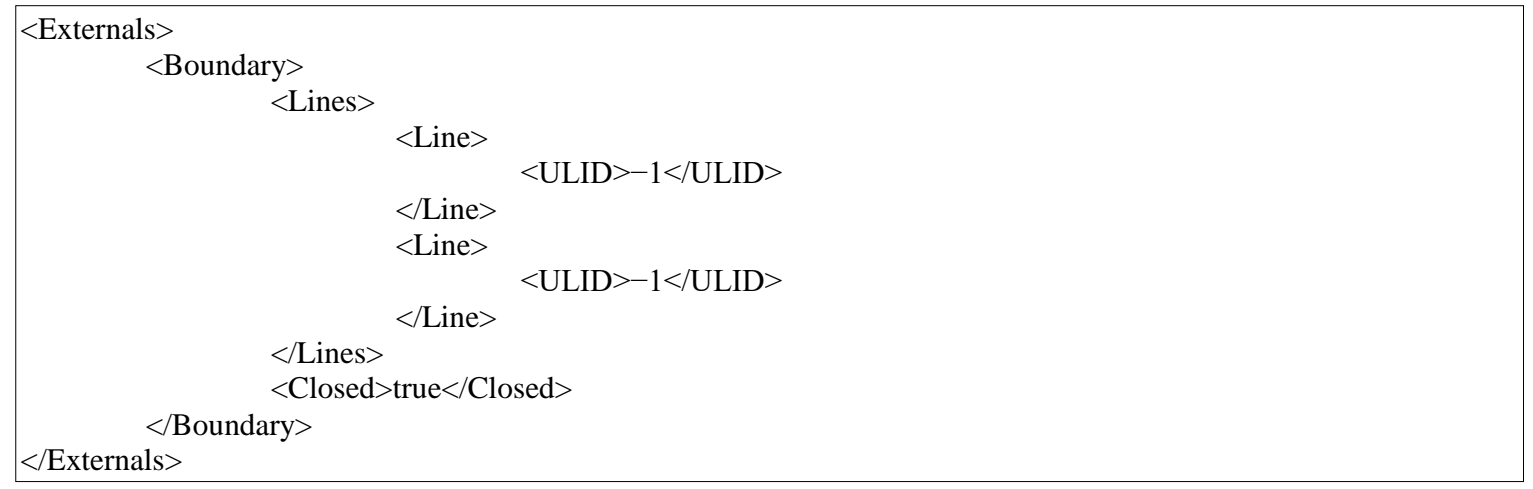

Fig. 15. Representation of the objects geometry of the first generation of cadastral exchange file markup language

\section{Conclusions and proposals}

During the transition from IN4 to XML, the recompilation of the information on which the cadastral system in Ukraine works was carried out. In particular, an attempt was made to get closer to the structure of information and its preservation by means of a cadastral file. However, in general, the data structure remained open and required the finalization.
Given the historical aspects of the development of the Ukrainian cadastral exchange file, the following should be noted:

- The IN4 format was based on the INI format;

- IN4 realized a simple vector model for describing geometry;

- XML-based cadastral exchange file should be considered as file implemented using the cadastral exchange file markup language; 
- XML-based cadastral exchange file implemented a topological model;

- XML-based cadastral exchange file used an object-oriented approach to describe complex structured information.

Given the potential for using XML in the implementation of the cadastral exchange file, it is necessary to perform:
- object description of complex structured data requires a major revision;

- the cadastral exchange file markup language needs to be defined as such and fixed in the legal field.

\section{References}

1. Bourret, Ronald. XML and Databases [online]. 2005. url: http://www.rpbourret.com/xml/XMLAndDatabases.htm.

2. Bray, Tim et al. Extensible Markup Language (XML). 1.1 (Second Edition). 2006, p. 45. url: http://www.w3pdf.com/W3cSpec/XML/2/REC-Xml11-20060816.pdf.

3. Burggraf, David, ed. OGC KML 2.3. 2015, p. 266. url: http://docs.opengeospatial.org/is/12-007r2/12-007r2.html.

4. Code Page 1251 Windows Cyrillic (Slavic) [online]. url: https://msdn.microsoft.com/en-us/library/cc195053.aspx

5. D., Fedorov. Digitals. Vykorystannya v heodeziyi, kartohrafiyi ta zemleustriy. TOV "Analityka", 2015, p. 354. url: http://geosystema.net/digitals/book/digitals-book.pdf.

6. Eryk, Rey. Izuchaem XML. Ed. by Halunov A. Sankt-Peterburh: Symvol-Plyus, 2001. P. 408

7. Example of WIN.INI Lines for an Invokable TP [online]. url: https://msdn.microsoft.com/en-us/library/ee251978(v=bts.10).aspx.

8. Fayly initsializatsiyi .ini [online]. url: https://uk.wikipedia.org/wiki/.ini.

9. File Extension INFO [online]. url: http://file.downloadatoz.com/info-file-extension/.

10. Heodezychna informatsiyna systema 6. chast II. ukovodstvo polzovatelya, p. 248. url: http://shels.com.ua/download/gis6_doc2.pdf.

11. .INFO File [online]. url: http://filext.com/file-extension/INFO.

12. Invent-HRAD v 2.01. url: http://kadastrua.ru/stati/865-invent-grad.html.

13. JSON Schema [online]. url: http://json-schema.org/.

14. Lisovyy kodeks Ukrayiny. Kodeks [online]. 1994. url: http://zakon2.rada.gov.ua/laws/show/3852-12.

15. Lupp, Dr. Markus, ed. Styled Layer Descriptor Implementation Specification. 2007 , p. 54. url: http://www.opengeospatial.org/standards/sld.

16. Mertz, David. XML Matters: Putting XML in context with hierarchical, relational, and object-oriented models. 2001, p. 7. url: https://www.ibm.com/developerworks/library/x- matters8/x-matters8-pdf.pdf.

17. Overview of INF Files [online]. url: https://docs.microsoft.com/uk- ua/windows- hardware/drivers/install/overview-of-inf-files.

18. O.YE., Tolchevska and Konyayev YU.H. ?HIS tekhnolohiyi u zemleustroyi? In: Ekolohichna bezpekata pryrodokorystuvannya (2014) [online], pp. 168-179. url: http://irbis-nbuv.gov.ua/cgi-bin/irbis_nbuv/cgiirbis 64.exe?C21COM=2\&I21DBN=UJRN\&P21DBN=UJRN\&IMAGE_FILE_DOWNLOAD=1\&Image_file_name=PDF/ebpk_2014 _14_19.pdf.

19. Portele, Clemens, ed. Geography Markup Language (GML) — Extended schemas and encoding rules. 2012, p. 91. url: http://www.opengeospatial.org/standards/gml.

20. Pro kurorty. Zakon Ukrayiny [online], 2000. url: http://zakon2.rada.gov.ua/laws/show/2026-14.

21. Pro pryrodno-zapovidnyy fond Ukrayiny. Zakon Ukrayiny [online], 1992. url: http://zakon5.rada.gov.ua/laws/show/2456-12.

22. Pro rehulyuvannya mistobudivnoyi diyalnosti. Zakon Ukrayiny [online]. 2011. url: http://zakon3.rada.gov.ua/laws/show/3038-17.

23. Pro zatverdzhennya Polozhennya pro rehionalni kadastry pryrodnykh resursiv. Postanova kabinetu ministriv Ukrayiny [online]. 2001. url: http://zakon2.rada.gov.ua/laws/show/1781-2001-\%D0\%BF

24. Pro zatverdzhennya Poryadku funktsionuvannya natsionalnoyi systemy otsinky antropohennykh vyky-div ta absorbtsiyi parnykovykh haziv, yaki ne rehulyuyutsya Monrealskym protokolom pro rechovyny, shcho ruynuyut ozonovyy shar. Postanova kabinetu ministriv Ukrayiny [online]. 2006. url: http://zakon2.rada.gov.ua/laws/show/554-2006-\%C3\%90\%C2\%BF.

25. Pro zatverdzhennya vymoh do struktury, zmistu ta formatu faylu obminu danymy rezultativ zemlev-poryadnykh robit u elektronnomu vyhlyadi na mahnitnykh nosiyakh. Nakaz derzhavnoho komitetu Ukrayiny z zemelnykh resursiv (Derzhkomzem Ukrayiny) [online]. 2003.

26. Prohramni zasoby dlya roboty $\mathrm{z}$ prostorovymy danymy url: $\begin{array}{lllll}\text { https://buksis.nethouse.ua/static/doc/0000/0000/0031/31531.kdmks50i30.pdf. } & \\ \text { Rukovodstvo } & \text { polzovatelya } & \text { TopomapGeodezia } & 1.2 & \text { [online]. }\end{array}$

27. Rukovodstvo polzovatelya TopomapGeod
pro.com.ua/topomapgeodezia/topomapgeodezia_ug.doc

28. RX Schema [online]. url: http://rx.codesimply.com/.

29. Scalable Vector Graphics (SVG). 1.1 (Second Edition). 2011, p. 826. url: https://www.w3.org/TR/SVG11/REC-SVG1120110816.pdf.

30. Windows-1251 [online]. url: https://uk.wikipedia.org/wiki/Windows-1251.

31. XML technology [online]. url: https://www.w3.org/standards/xml/.

32. XML, the New Database Heresy [online]. url: http://www.25hoursaday.com/weblog/PermaLink.aspx?guid=d28ce1fb-7b27-407db1a3-0b9a34831ca1. 